\title{
Identifying the Carbon Emissions Damage to International Tourism: Turn a Blind Eye
}

\author{
Muhammad Khalid Anser ${ }^{1}$, Zahid Yousaf $\left.{ }^{2} \mathbb{(}\right)$, Usama Awan ${ }^{3, *} \mathbb{C}$, Abdelmohsen A. Nassani ${ }^{4}$, \\ Muhammad Moinuddin Qazi Abro ${ }^{4}$ and Khalid Zaman ${ }^{5}$ \\ 1 Department of Public Administration, Xi'an University of Architecture and Technology, Xi'an 710000, China; \\ mkhalidrao@xauat.edu.cn \\ 2 Higher Education Department Khyber Pakhtunkhwa, Government College of Management Sciences, \\ Abbottabad 22060, Pakistan; muhammadzahid.yusuf@gmail.com \\ 3 Industrial Engineering and Management, Lappeenranta-Lahti University of Technology LUT, P.O. Box 20, \\ FI-53851 Lappeenranta, Finland \\ 4 Department of Management, College of Business Administration, King Saud University, P.O. Box 71115, \\ Riyadh 11587, Saudi Arabia; Nassani@ksu.edu.sa (A.A.N.); qaziabro@gmail.com (M.M.Q.A.) \\ 5 Department of Economics, University of Wah, Quaid Avenue, Wah Cantt 47040, Pakistan; \\ dr.khalidzaman@uow.edu.pk \\ * Correspondence: usama.awan@lut.fi
}

Received: 30 January 2020; Accepted: 21 February 2020; Published: 3 March 2020

check for updates

\begin{abstract}
The importance of sustainable tourism is largely discussed in environmental literature under two different main streams: first, an ample amount of literature is available on the role of international tourism in economic development; second, the existing literature mainly focused on estimating tourism carbon footprints across countries. Limited work has been done on identifying the cost of carbon emissions on the tourism industry, which is evaluated in this study to fill the existing literature gap by using a large panel of 132 countries between 1995 and 2018. The results show that carbon emissions damage, methane $\left(\mathrm{CH}_{4}\right)$, nitrous oxide $\left(\mathrm{N}_{2} \mathrm{O}\right)$ emissions, and population density substantially decrease inbound tourism and international tourism receipts that result in an impact on the increase in international tourism expenditures across countries. The ex-ante analysis shows that inbound tourism will likely decrease from $19.546 \%$ to $16.854 \%$ due to an increase in carbon emissions damage of $0.357 \%$ to $1.349 \%$ for the period $2020-2028$. Subsequently, international tourism expenditures will decrease from $19.758 \%$ to $12.384 \%$ by increasing carbon emissions damage from $0.832 \%$ to $1.025 \%$. Finally, international tourism revenues will subsequently decline from $23.362 \%$ to $18.197 \%$ due to lowering carbon emissions damage from $0.397 \%$ to $-0.113 \%$ over a time horizon.
\end{abstract}

Keywords: Carbon emissions damage; international tourism; methane emissions; nitrous oxide emissions; population density; differenced GMM estimator

\section{Introduction}

The evaluation of the true cost of carbon emissions on economic sectors is needed for the globalized world to formulate sustainable economic policies in order to limit negative environmental externalities [1]. International tourism (INTL_TOUR) is the leading service sector in terms of revenue generation in most of the developed and developing countries that are affiliated with high carbon costs [2,3]. According to a UNWTO [4] report, inbound tourism increased by $5 \%$ in the year 2018, which reaches 1.4 billion tourist arrivals worldwide, while at the same time, a $4 \%$ increase in tourism export earnings reached $\$ 1.7$ trillion USD worldwide. The growth in inbound tourism and its income receipts outpaced the global economic growth that benefited high-income countries and emerging economies. It is impressive that INTL_TOUR exports grew faster than the merchandise exports that 
help to improve the trade account in the balance of payments in many developed and developing countries. The need for effective destination management in terms of eco-friendly tourism is a priority of the globalized world in order to ensure carbon-free tourism. Advancement of cleaner production technologies, innovation, digitalization, and societal changes are few of the anticipatory factors that would help attract foreign tourists to safe and healthy destinations on a global scale. A New York Times [5] report showed some significant changes in the global industrial emissions, which rose $1.5 \%$ in 2017 to $2.1 \%$ in the year 2018; however, a significant decline was found in 2019 that hit $0.6 \%$ emissions. The substantial decline was viewed in industrial emissions and coal production in the European Union, the United States, and India, as these economies largely cut their carbon output. The coal-fueled growth in China has been substantially declining since 2010, which limits emissions to an average increase of $0.9 \%$, where coal is substituted by cleaner production technologies, renewable fuels, and sustainable infrastructure development.

The importance of INTL_TOUR development in socio-economic and environmental sustainability is largely visible in the United Nations sustainable development goals (SDGs) that emphasize the need for sustainable policy actions in order to conserve the natural environment. The following four United Nations SDGs are directly related with INTL_TOUR, i.e., SDG-8, SDG-9, SDG-12, and SDG-13, which are related to decent work and economic growth, industries, innovation, and infrastructure, responsible consumption and production, and climate change, respectively [6]. This study works on these stated SDGs in order to analyze the global vision of tourism sustainability and green development agenda for concrete policy findings. The previous studies largely confounded the role of INTL_TOUR in a country's economic growth and sustainable development efforts [7-9], while a little work has been done on identifying the carbon emissions damage on INTL_TOUR, which is one of the real motivation to extend the analysis across the globe.

It is evident that INTL_TOUR exhausts natural and wildlife resources, as 70\% of marine mammals, $80 \%$ of the global coral reefs, and around $25 \%$ of mangroves are endangered due to ecological footprints. Thus, sustainable tourism is an optimized solution to conserve natural and wildlife resources through integrated socio-economic and environmental policies across the globe [10]. The real problem for the implementation of global environmental sustainability policy is to make a set of proposed actions through which countries may limit anthropogenic activities that disrupt the United Nations resource conservation agenda. The emissions intensity (I), population growth $(\mathrm{P})$, affluence (A), and technology (T) (IPAT) is another important dimension of earlier literature, which confirms the massive destruction of environmental quality through an enormous increase in the global population growth. The process of a country's transformation from development to sustainable development through modern technologies would be the one action programme through which countries may sustain their environmental resources [11-13]. The eco-tourism initiative remains the main focal area through which countries may achieve green development [14].

This paper is organized as follows: Section 2 is devoted to the literature review, Section 3 shows material and methods, Section 4 presents the results of the study, Section 5 presents a discussion of the results, and the final section concludes the study.

\section{Literature Review}

An ample amount of literature is available on sustainable tourism, however, very little literature is available on identifying the carbon costs modelling in INTL_TOUR in a large panel of countries. For instance, Tiwari et al. [15] interlinked INTL_TOUR development with climate change and energy demand in a panel of 25 OECD countries for a period of 1995-2005. The results show that tourism infrastructure required more energy in order to generate economic activities, which negatively affect the global climate. Policies to achieve energy efficiency in the tourism sector are largely needed to ensure progress in sustainable tourism. Lee and Brahmasrene [16] selected a panel of European countries to analyze the role of INTL_TOUR on economic growth and carbon emissions for a period of 1988-2009. The results show that INTL_TOUR promotes economic growth that results in a negative 
impact on environmental quality. The eco-friendly tourism policies are imperative to combat climate change through sustainable instruments. Sajjad et al. [17] used the buzz word "nightmare" for climate change and air pollution that negatively affects INTL_TOUR during the empirical illustration of world aggregated data for the period of 1975-2012. The results show that natural resource depletion is the fair cause of inbound tourism that affects sustainable tourism agenda. There is a high need to conserve natural resource management in order to protect the tourism industry from environmental externalities. Ozturk et al. [18] collected the data of a large panel of 144 countries to evaluate the Environmental Kuznets Curve (EKC) hypothesis under tourism ecological footprints and confirmed the EKC hypothesis in upper-middle and high-income countries. There is a high need to reduce rural-urban migration and increase trade openness that supports to increase inbound tourism across countries. Another study by Ozturk [19] argued that the global economy should have to respond to limit high mass carbon emissions, which are embodied in unsustainable tourism planning. Bac and Aksoz [20] discussed different potential factors of INTL_TOUR that can negatively affect eco-friendly tourism across countries. The main factors include mass tourism, dystopia, meagre tourism marketing, regional challenges, and tourism pricing. Thus, these factors need to be corrected for making efficient sustainable tourism policies at a global scale. Tang et al. [21] analyzed the role of INTL_TOUR, energy and income in the context of India by using a data set of 1971-2012. The results showed the positive relationship between INTL_TOUR and energy demand that supports to increase country's economic growth. Moreover, the tourism led growth (TLG) hypothesis is unable to transform the same results for the energy-led growth hypothesis; thus, there is a considerable need to make energy-efficient policies and growth-oriented INTL_TOUR policies, which are moving toward the long-term growth of the country. Zaman et al. [22] examined the relationship between INTL_TOUR and carbon emissions under the number of following mediating factors including energy demand, healthcare expenditures, and foreign investment in a panel of 34 countries and found that INTL_TOUR increases carbon emissions in the viability of inverted U-shaped EKC, which is further linked with the healthcare sustainability to promote INTL_TOUR with continued economic growth. The study concludes that sustainable INTL_TOUR is imperative for limiting negative environmental externalities to follow carbon-free INTL_TOUR across countries. Malik et al. [2] argued that expansion in INTL_TOUR infrastructure leads to biodiversity loss through a channel of increase in the population pressure per square $\mathrm{km}$ of land area. This result is checked in the Australian context by utilizing the time series data from 1975-2015. The results show that inbound tourism deteriorates environmental quality under the viability of the TLG hypothesis. This implies that INTL_TOUR supports economic growth at the cost of carbon emissions, leading to the need to reduce dependency on fossil fuel energy in order to enlarge sustainable INTL_TOUR agenda. Qureshi et al. [23] found that INTL_TOUR increases carbon emissions that negatively affect tourist's health and wealth, which substantiates the carbon-induced EKC hypothesis and GHG-induced EKC hypothesis, using a panel of 37 heterogonous countries. The results further validated the TLG hypothesis across countries. The study concluded that INTL_TOUR is overcrowded with environmental pollutants that sabotaged the environmental sustainability agenda on a global scale. Zaman et al. [24] concluded that energy-associated carbon emissions are negatively influenced to the country's sustainable INTL_TOUR agenda; they used a panel of 11 transition economies for the period of 1995-2013. Their results further endorsed the concept that INTL_TOUR embodied emissions and economic growth that simultaneously exists in a given model indicate the need for effective INTL_TOUR management across countries. Nassani et al. [25] determined the role of INTL_TOUR in view of military support for a panel of 18 countries by using a time series data from 1995-2014 and concluded that tourists are likely to increase healthy visitation in the safe environment where they feel protected and less violent. The results supported the TLG and tourism-led military expenditures hypothesis and emphasized the need to protect international tourists under arms protection. The policies should be made for long-term sustained tourism growth on a global scale. Khan et al. [26] investigated the possible determinants of inbound tourism in a panel of 19 countries and found that air-railways transportation increases the international tourist count that support a country's economic 
growth. The soundness of the aviation sector and road infrastructure is desirable in order to promote INTL_TOUR infrastructure, which leads to an increase in economic growth across countries.

Paramati et al. [27] analyzed the role of INTL_TOUR on environmental quality in a large panel of Eastern and Western European countries and confirmed that INTL_TOUR increase carbon emissions in Eastern Europe, while this result is inverted in Western Europe. The causality estimates confirmed the tourism led emissions in Eastern Europe, while the reverse holds in Western Europe. The results largely conveyed the importance of INTL_TOUR in promoting a country's economic growth. However, while devising any sustainable INTL_TOUR policy agenda, it is imperative to limit tourism carbon footprints, which is the serious concern of the United Nations to mitigate emissions through green technologies. Nassani et al. [28] emphasized the need to integrate INTL_TOUR with socio-economic factors and found that domestic violence decreases INTL_TOUR under the viability of crime Kuznets curve in a panel of 16 countries. The results confirmed the cause-effect relationship between crime rate, INTL_TOUR, and economic growth. The crime regulated policies and INTL_TOUR support policies should be interlinked that would be helpful to attain long-term payoffs in the form of increasing inbound tourism and INTL_TOUR revenues. Bhuiyan et al. [29] focused on the interrelationships among INTL_TOUR, finance, and resource depletion in a heterogeneous panel of countries for a period of 1995-2016. The results show that INTL_TOUR deteriorate natural environment in the form of energy and resource depletion under the mediating channel of financial development indicators and renewable energy sources. The advancement in the green technologies and environmental regulations would be helpful to achieve sustainable INTL_TOUR agenda across countries. Shaheen et al. [30] utilized the panel data for the top 10 tourists induced countries for a period of 1995-2016 and confirmed the visibility of the EKC hypothesis across countries. Moreover, the study shows the two-way linkages between INTL_TOUR receipts and energy demand, and carbon emissions and outbound tourism, while one-way linkage is established under GDP per capita and INTL_TOUR in a given time period. The policies for energy conservation and resource depletion would be desirable to proceed towards sustainable INTL_TOUR development. Anser et al. [31] considered a panel of G-7 countries and evaluated sustainable INTL_TOUR agenda using the multifaceted factors during the period of 1995-2015. The results show the feedback relationship between INTL_TOUR and income of the country, whereas a one-way linkage was found from INTL_TOUR to carbon emissions, investment to INTL_TOUR income, social expenditures to INTL_TOUR receipts, and inequality to INTL_TOUR across countries. The study concludes that there is a need to redistribute national income for the efficient use of a country's resources to promote and develop sustainable tourism. Ali et al. [32] considered a case study of the Malaysian economy to identify the macroeconomic factors that positively influenced INTL_TOUR towards long-term growth. The results emphasized the need to limit hike in oil prices, high currency exchange rate in terms of USD, and capital exports in a country. Zhang and Zhang [33] argued that the expansion of INTL_TOUR infrastructure required more energy that increases environmental concerns, which is the subject matter of INTL_TOUR sustainability. Tang et al. [34] considered the case study of Beijing, China in order to evaluate the INTL_TOUR and emissions nexus and confirmed that inbound tourism negatively influenced carbon emissions, which required sustainable INTL_TOUR policies to achieve energy efficiency. Table 1 shows the recent strikes of literature on sustainable INTL_TOUR across countries.

The stated studies confirmed the need to devise eco-tourism policies in order to proceed for long-term sustainable development across countries. 
Table 1. Literature review on sustainable tourism.

\begin{tabular}{|c|c|c|c|c|}
\hline Authors & Time Period & Country & Results & Hypothesis Support \\
\hline Qureshi et al. [35] & 1995-2016 & 35 countries & 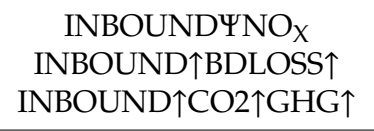 & To verify INTL_TOUR ecological footprints. \\
\hline Anser et al. [31] & 1995-2015 & G-7 countries & $\begin{array}{c}\mathrm{ITR} \uparrow \mathrm{CO} 2 \uparrow \\
\mathrm{FDI} \uparrow \mathrm{CO} 2 \uparrow \\
\mathrm{CO} 2 \Omega \mathrm{EG}\end{array}$ & $\begin{array}{l}\text { To substantiate tourism led emissions, pollution haven } \\
\text { hypothesis and EKC hypothesis. }\end{array}$ \\
\hline Balsalobre-Lorente et al. [36] & 1994-2014 & Selected OECD countries & ITOUR $\Omega$ CO2 & To validate tourism-induced Kuznets curve. \\
\hline Manzoor et al. [37] & 1990-2015 & Pakistan & ITOUR $\uparrow E G \uparrow$ & To confirm tourism-induced economic growth. \\
\hline Khan et al. [38] & 1995-2017 & 34 countries & $\begin{array}{l}\text { ITOUR } \leftrightarrow \text { ENRG } \\
\text { ITOUR } \rightarrow \text { GHG }\end{array}$ & $\begin{array}{l}\text { Region-wise analysis confirmed the feedback hypothesis } \\
\text { between INTL_TOUR and energy demand in America, } \\
\text { whereas tourism-led emissions is supported in Asia, } \\
\text { Europe, and America. }\end{array}$ \\
\hline He et al. [39] & 2005-2013 & 30 Chinese provinces & TFP $\uparrow$ TEF $\uparrow$ & $\begin{array}{c}\text { Sustainable INTL_TOUR agenda could be achieved } \\
\text { through attaining energy efficiency in total factor } \\
\text { productivity. }\end{array}$ \\
\hline Liu et al. [40] & 1980-2016 & Pakistan & $\begin{array}{l}\mathrm{EG} \rightarrow \mathrm{CO} 2 \\
\mathrm{ENRG} \rightarrow \mathrm{CO} 2 \\
\mathrm{ITOURЙCO} 2\end{array}$ & $\begin{array}{c}\text { To verify energy led emissions and growth led emissions, } \\
\text { whereas no cause-effect relationship was found between } \\
\text { INTL_TOUR and carbon emissions in a country. }\end{array}$ \\
\hline Sghaier et al. [41] & 1980-2014 & Tunisia, Egypt, and Morocco & ITOUR $\uparrow \mathrm{CO} 2 \uparrow$ & $\begin{array}{l}\text { INTL_TOUR induced carbon emissions is found in } \\
\text { Egypt. }\end{array}$ \\
\hline Koçak et al. [42] & 1995-2014 & 10 countries & $\begin{array}{l}\text { INBOUND } \uparrow \mathrm{CO} 2 \uparrow \\
\text { ITR } \uparrow \mathrm{CO} 2 \downarrow \\
\text { ITOUR } \leftrightarrow \mathrm{CO} 2\end{array}$ & $\begin{array}{l}\text { To confirm the feedback hypothesis between } \\
\text { INTL_TOUR and carbon emissions across countries. }\end{array}$ \\
\hline Huiyue and Meng [43] & 2005-2015 & China & $\begin{array}{c}\mathrm{EG} \uparrow \mathrm{CO} 2 \uparrow \\
\mathrm{ITOUR} \uparrow \mathrm{EG} \uparrow \mathrm{CO} 2 \downarrow\end{array}$ & $\begin{array}{l}\text { INTL_TOUR supports a country's economic growth that } \\
\text { resulting impact on decreasing carbon emissions across } \\
\text { countries. }\end{array}$ \\
\hline
\end{tabular}




\section{Material and Method}

\subsection{Research Questions, Research Objectives, and Contribution of the Study}

The main research question of the study is whether the cost of carbon emissions on INTL_TOUR is highly influenced by the United Nations sustainability agenda in the form of tourists' healthy visitation to the tourists' destination point. This question is important to evaluate on account of formulating sustainable INTL_TOUR policies that should be carbon-free. The question should be under consideration during the empirical illustrations, i.e., To what extent carbon emissions damage, $\mathrm{CH}_{4}$ emissions, and $\mathrm{N}_{2} \mathrm{O}$ emissions influenced inbound tourism, INTL_TOUR receipts, and INTL_TOUR expenditures across countries?

This question is very important from a policy perspective, as the energy sector releases $\mathrm{CH}_{4}$ emissions and $\mathrm{N}_{2} \mathrm{O}$ emissions that result in a share in carbon damage being attributed to INTL_TOUR. Tourists are likely to reduce the length of stay in non-hygienic tourism spots where the natural scenic view is depleted due to negative environmental externalities, resulting in lower INTL_TOUR revenues. Further, an unsafe healthy destination put a burden on tourists' out-of-pocket healthcare expenditures, which increases INTL_TOUR expenditures. The state should have to work on mitigating carbon damage the preservation of natural and cultural heritage, and should spend an enormous amount on INTL_TOUR development for safe and healthy visitation. Based on the research questions, the study has a following research objectives:

1. To identify the cost of carbon emissions on INTL_TOUR in a panel of 132 countries;

2. To evaluate the cost of $\mathrm{CH}_{4}$ and $\mathrm{N}_{2} \mathrm{O}$ emissions on INTL_TOUR;

3. To analyze the causal relationships between INTL_TOUR, emissions, population density, and economic growth across countries; and

4. To determine the ex-ante analysis between the candidate variables for the next 10 years time period.

The study makes a novel contribution to the existing literature of sustainable INTL_TOUR in three different ways. First, the previous studies largely analyzed the relationship between INTL_TOUR and economic growth based on the premises of carbon emissions and found to prove some causal channels between them [22,24,44-46]. However, these studies do not evaluate carbon emissions damage on INTL_TOUR in relation population density and economic growth, which is incorporated in this study. Second, earlier studies are limited to include energy associated emissions $[7,47,48]$ in eco-tourism agenda, while in this study, we used carbon emissions damage, methane emissions, and nitrous oxide emissions in carbon-tourism modelling to identify the costs of different emissions on INTL_TOUR. Finally, previous studies rarely calculated the share of carbon emissions damage in decreasing inbound tourism, INTL_TOUR receipts, and expenditures [49,50]. This study, however, used ex-ante analysis to find the percentage share of carbon emissions damage, $\mathrm{N}_{2} \mathrm{O}$ emissions, $\mathrm{CH}_{4}$ emissions, and population density over INTL_TOUR for next 10 years.

\subsection{Variables and Data Source}

The study used the following key variables in order to determine the cost of carbon emissions on INTL_TOUR in a panel of 132 countries, i.e., inbound tourism (denoted by INBOUND), international tourism expenditures as a percentage of total imports (denoted by ITEXP), international tourism receipts as a percentage of total exports (denoted by ITRCPT), carbon emissions damage as a percentage of GNI (denoted by $\left(\mathrm{CO}_{2}\right.$ DAM), methane emissions in energy sector as $000^{\prime}$ metric tons of carbon equivalent (denoted by $\mathrm{CH}_{4}$ ), nitrous oxide emissions as a percentage of total energy demand (denoted by $\mathrm{N}_{2} \mathrm{O}$ ), population density as people per square $\mathrm{km}$ of land area (denoted by POP_DEN), and GDP per capita in constant 2010 USD (denoted by GDPpc). The World Bank [51] database is used to collect time-series data for the given variables. A few of the variables were missing from the given database across different countries, so these gaps were filled by the succeeding and preceding values of the same 
variable in order to minimize the possible variations in the given data set. Table A1 in the appendix shows the list of countries that were used as a sample in this study.

\subsection{Correlation Matrix}

Table 2 shows the variables description and their possible relationship during the period of 1995-2018. The statistics show that there is a number of international tourists that visit across the selected countries with an average value count of $5,984,127$. The mean value of tourism revenue is about to $14.071 \%$ in terms of exports, while its expenditures are $6.322 \%$ of total imports. The maximum value of carbon damages as a percentage of GNI is reported about $15.301 \%$ with a minimum value of $0.062 \%$ that reached an average value of $1.498 \%$. The average value of $\mathrm{CH}_{4}$ and $\mathrm{N}_{2} \mathrm{O}$ emissions released by energy demand was about to reach $17,868.37$ as $000^{\prime}$ metric tons of carbon equivalent and $7.681 \%$ of total energy consumption, respectively. About 180.436 people per square $\mathrm{km}$ of land area are shown as an average value in the selected panel of countries with a per capita income of $\$ 12,725.51$ USD. The given statistics show the trend analysis of the individual variables that would be helpful to find the correlation among the variables.

Table 2. Descriptive statistics and correlation matrix.

\begin{tabular}{ccccccccc}
\hline Methods & INBOUND & ITEXP & ITRCPT & CO2_DAM & $\mathbf{C H}_{\mathbf{4}}$ & $\mathbf{N}_{\mathbf{2}} \mathbf{O}$ & POP_DEN & GDPPC \\
\hline Mean & $5,984,127$ & 6.322 & 14.071 & 1.498 & $17,868.37$ & 7.681 & 180.436 & $12,725.51$ \\
\hline Maximum & $86,861,000$ & 42.440 & 170.479 & 15.301 & $738,366.8$ & 39.993 & $7,952.998$ & $111,968.3$ \\
\hline Minimum & 700 & 0.183 & 0.00095 & 0.062 & 0.598 & 0.153 & 1.479 & 183.547 \\
\hline Std. Dev. & $1,211,2342$ & 4.134 & 15.753 & 1.536 & $65,794.95$ & 5.639 & 608.134 & $18,104.68$ \\
\hline Skewness & 3.675 & 2.161 & 2.425 & 3.185 & 7.656 & 1.518 & 9.936 & 2.254 \\
\hline Kurtosis & 18.478 & 11.768 & 12.041 & 17.458 & 70.491 & 6.213 & 110.863 & 8.662 \\
\hline
\end{tabular}

Correlation Matrix

\begin{tabular}{|c|c|c|c|c|c|c|c|c|}
\hline INBOUND & 1 & & & & & & & \\
\hline ITEXP & $-0.032^{* * *}$ & 1 & & & & & & \\
\hline ITRCPT & $-0.121^{*}$ & $0.277^{*}$ & 1 & & & & & \\
\hline $\mathrm{CO}_{2} \mathrm{DAM}$ & -0.027 & $-0.033^{* * *}$ & $-0.163^{*}$ & 1 & & & & \\
\hline $\mathrm{CH}_{4}$ & $0.455^{*}$ & $0.049^{*}$ & $-0.141^{*}$ & $0.239^{*}$ & 1 & & & \\
\hline $\mathrm{N}_{2} \mathrm{O}$ & $0.271^{*}$ & 0.017 & 0.008 & $-0.081^{*}$ & $0.120^{*}$ & 1 & & \\
\hline POP_DEN & 0.014 & -0.028 & 0.029 & $-0.089^{*}$ & $-0.034^{* * *}$ & $0.031^{* * *}$ & 1 & \\
\hline GDPpc & $0.352^{*}$ & $0.097^{*}$ & $-0.188^{*}$ & $-0.264^{*}$ & 0.0093 & $0.424^{*}$ & $0.153^{*}$ & 1 \\
\hline
\end{tabular}

Note: ${ }^{*}$ and ${ }^{* * *}$ indicates $1 \%$ and $10 \%$ level of significance.

The correlation results of Table 2 shows that there is a negative correlation between carbon emissions damage and (i) inbound tourism (i.e., $r=-0.027$ ), (ii) INTL_TOUR expenditures (i.e., $\mathrm{r}=-0.033, p<0.05$ ), and (iii) INTL_TOUR receipts (i.e., $\mathrm{r}=-0.163, p<0.000$ ) whereas the rest of the variables have a mixed results with the INTL_TOUR factors. The methane emissions have a positive correlation with INBOUND and ITEXP, while the negative correlation with ITRCPT. The nitrous oxide emissions have a positive correlation with INTL_TOUR factors. The population density negatively correlated with the ITEXP while positively correlated with the INBOUND and ITRCPT. Finally, the continued economic growth support to INBOUND and ITEXP is negatively correlated with the ITRCPT. The mixture of results obtained from the correlation matrix needs a more robust statistical method in order to examine the functional relationship between the stated variables. Before going to the empirical side, we will present the theoretical framework of the study. 


\subsection{Conceptual Framework}

Sustainable tourism falls into the category of social exchange theory, environmental justice, and spatial distributive differences that gives new insights for go-for-green sustainable policies across countries. This study followed an endogenous growth model where economic activity is subject to different socio-economic and environmental factors, which can be found using a different version of the Solow growth model [52], i.e.,

$$
Y=A f(L, K) \ldots \ldots \ldots \cdot \frac{\partial Y}{\partial L}>0, \frac{\partial Y}{\partial K}>0, \frac{\partial Y}{\partial A}>0
$$

where Y shows economic growth, A shows knowledge/technology, K shows capital stock, and L shows labor stock.

The corresponding L, K, and A on Y will be positively influenced, which would be helpful to increase economic activities across countries. Environmental degradation is the consequence of continued economic activity, which accounts for high industrialization and rapid rural-urban migration. The resultant matrix is an increasing carbon emissions stock that negatively influenced global economic growth. Thus, Equation (2) can be written as follows:

$$
C=A f(Y, P, K) \ldots \ldots \ldots \cdot \frac{\partial C}{\partial Y}>0, \frac{\partial C}{\partial K}>0, \frac{\partial C}{\partial A}>0, \frac{\partial C}{\partial P}
$$

where $\mathrm{C}$ represents carbon emissions and $\mathrm{P}$ represents population growth.

It is likely that high economic growth increases carbon emissions due to the structural shift from an agriculture-based society to an industrial-based society, whereas an increase in capital stock further escalates carbon emissions due to unsustainable foreign investment in order to support the pollution haven hypothesis. Technology-embodied emissions are another important factor that could be reduced by sustainable knowledge spillovers, while higher population growth would tend to increase carbon emissions stock to substantiate the IPAT hypothesis at a global scale. It is quite evident that carbon emissions damage the natural flora of the country; thus there is a high need to evaluate the true cost of environmental emissions on INTL_TOUR, as INTL_TOUR is considered as an engine of economic growth [53,54]. Equation (3) shows the following:

$$
\begin{aligned}
& \ln \left(\begin{array}{l}
\text { INBOUND } \\
\begin{array}{l}
\text { ITEXP } \\
\text { ITRCPT }
\end{array}
\end{array}\right\rangle_{i, t}=\ln \left[A\left(\mathrm{CO}_{2} \_D A M\right)^{\alpha 1}\left(\mathrm{CH}_{4}\right)^{\alpha 2}\left(\mathrm{~N}_{2} \mathrm{O}\right)^{\alpha 3}\left(\mathrm{POP}_{-} D E N\right)^{\alpha 4}(\mathrm{GDPpC})^{\alpha 5} \varsigma\right]_{i, t} \\
& \begin{array}{l}
\ln \left(\begin{array}{l}
\operatorname{INBOUND} \\
\operatorname{ITEXP} \\
\operatorname{ITRCPT}
\end{array}\right\rangle_{i, t}^{i, t}=\alpha_{0}+\alpha_{1} \ln \left(\mathrm{CO}_{2} \_D A M\right)_{i, t}+\alpha_{2} \ln \left(\mathrm{CH}_{4}\right)_{i, t}+\alpha_{3} \ln \left(\mathrm{N}_{2} \mathrm{O}\right)_{i, t}+\alpha_{4} \ln (\text { POP_DEN })_{i, t} \\
+\alpha_{5} \ln (\mathrm{GDPpC})_{i, t}+\ln (\varsigma)
\end{array} \\
& \ln \langle\text { INBOUND }\rangle_{i, t}=\alpha_{0}+\alpha_{1} \ln \left(\mathrm{CO}_{2} \mathrm{DAM}_{i, t}+\alpha_{2} \ln \left(\mathrm{CH}_{4}\right)_{i, t}+\alpha_{3} \ln \left(\mathrm{N}_{2} \mathrm{O}\right)_{i, t}+\alpha_{4} \ln (\text { POP_DEN })_{i, t}\right. \\
& +\alpha_{5} \ln (G D P p c)_{i, t}+\ln (\varsigma) \\
& \therefore \frac{\partial \ln (\text { INBOUND })_{i, t}}{\partial \ln \left(\mathrm{CO}_{2} \_ \text {DAM }\right)_{i, t}}<0, \frac{\partial \ln (\text { INBOUND })_{i, t}}{\partial \ln \left(\mathrm{CH}_{4}\right)_{i, t}}<0, \frac{\partial \ln (\text { INBOUND })_{i, t}}{\partial \ln \left(N_{2} \mathrm{O}\right)_{i, t}}<0, \frac{\partial \ln (\text { INBOUND })_{i, t}}{\partial \ln \left(P_{-} P_{-} D E N\right)_{i, t}}<0 \text {, } \\
& \frac{\partial \ln (\text { INBOUND })_{i, t}}{\partial \ln (\mathrm{GDPpC})_{i, t}}>0 \\
& \ln \langle\text { ITEXP }\rangle_{i, t}=\alpha_{0}+\alpha_{1} \ln \left(\mathrm{CO}_{2} \_D A M\right)_{i, t}+\alpha_{2} \ln \left(\mathrm{CH}_{4}\right)_{i, t}+\alpha_{3} \ln \left(\mathrm{N}_{2} \mathrm{O}\right)_{i, t}+\alpha_{4} \ln (\text { POP_DEN })_{i, t} \\
& +\alpha_{5} \ln (G D P p c)_{i, t}+\varepsilon \\
& \therefore \frac{\partial \ln (\text { ITEXP })_{i, t}}{\partial \ln \left(C_{2} D A M\right)_{i, t}}>0, \frac{\partial \ln (\text { ITEXP })_{i, t}}{\partial \ln \left(C_{4}\right)_{i, t}}>0, \frac{\partial \ln (\text { ITEXP })_{i, t}}{\partial \ln \left(N_{2} O\right)_{i, t}}>0, \frac{\partial \ln (\text { ITEXP })_{i, t}}{\partial \ln \left({\text { POP_DEN })_{i, t}}_{2}\right.}>0, \frac{\partial \ln (\text { ITEXP })_{i, t}}{\partial \ln (G D P p c)_{i, t}}>0
\end{aligned}
$$




$$
\begin{aligned}
& \ln \langle\operatorname{ITRCPT}\rangle_{i, t}=\alpha_{0}+\alpha_{1} \ln \left(\mathrm{CO}_{2} \_D A M\right)_{i, t}+\alpha_{2} \ln \left(\mathrm{CH}_{4}\right)_{i, t}+\alpha_{3} \ln \left(\mathrm{N}_{2} \mathrm{O}\right)_{i, t}+\alpha_{4} \ln (\text { POP_DEN })_{i, t} \\
& +\alpha_{5} \ln (G D P p c)_{i, t}+\varepsilon \\
& \therefore \frac{\partial \ln (\text { ITRCPT })_{i, t}}{\partial \ln \left(\mathrm{CO}_{2}{ }_{2} D A M\right)_{i, t}}<0, \frac{\partial \ln (\text { ITRCPT })_{i, t}}{\partial \ln \left(\mathrm{CH}_{4}\right)_{i, t}}<0, \frac{\partial \ln (\text { ITRCPT })_{i, t}}{\partial \ln \left(N_{2} O\right)_{i, t}}<0, \frac{\partial \ln (\text { ITRCPT })_{i, t}}{\partial \ln \left(\text { POP_DEN }_{i, t}\right.}<0 \text {, } \\
& \frac{\partial \ln (\text { ITRCPT })_{i, t}}{\partial \ln (G D P p C)_{i, t}}>0
\end{aligned}
$$

where INBOUND represents inbound tourism, ITEXP represents tourism expenditures, ITRCPT represents tourism receipt, $\mathrm{CO}_{2}$ DAM represents carbon emissions damage, $\mathrm{CH}_{4}$ represents methane emissions, $\mathrm{N}_{2} \mathrm{O}$ represents nitrous oxide emissions, POP_DEN represents population density, GDPpc represents GDP per capita, ln represents natural logarithm, and $\Sigma$ represents error term.

Figure 1 shows the research framework of the study.

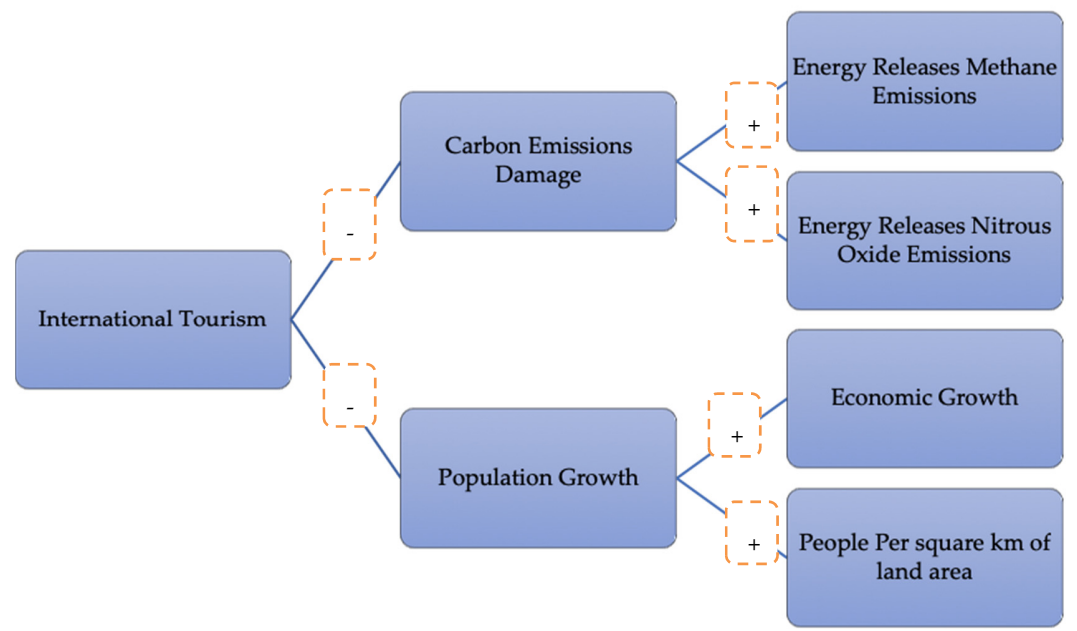

Figure 1. Research framework of the study. Source: authors' extraction.

Figure 1 shows the possible relationship between INTL_TOUR and its determinants in a panel of selected countries. It is expected that INTL_TOUR is largely influenced by carbon emissions damage that negatively affects the health and wealth of international tourists. Tourists would likely to visit safe and healthy tourisms spots, thus the need to safe and healthy INTL_TOUR is desirable for getting economic gains. Energy releases $\mathrm{CH}_{4}$ emissions and $\mathrm{N}_{2} \mathrm{O}$ emissions that likely to increase the share of carbon emissions that negatively affect inbound tourism, INTL_TOUR receipts, and expenditures. Population density is expected to have a negative impact on INTL_TOUR across countries. The following hypotheses are evaluated for empirical illustrations, i.e.,

Hypothesis (H1): The cost of carbon emissions affects inbound tourism, INTL_TOUR receipts, and INTL_TOUR expenditures;

Hypothesis (H2): Energy released from $\mathrm{CH}_{4}$ and $\mathrm{N}_{2} \mathrm{O}$ emissions will negatively affect INTL_TOUR; and

Hypothesis (H3): Population density and economic growth are expected to have a negative and positive impact on INTL_TOUR across countries.

\subsection{Econometric Framework}

Equations (3.1) to (3.3) show that inbound tourism and INTL_TOUR receipts are expected to have a negative relationship to carbon emissions damage, as the higher the cost of carbon emissions, the lower the inbound tourism and INTL_TOUR receipts. Further, the high emissions of $\mathrm{CH}_{4}$ and $\mathrm{N}_{2} \mathrm{O}$ are expected to influence negatively to inbound tourism and INTL_TOUR receipts, which is caused by the high energy demand on a global scale. The negative impact of population density 
and positive impact of country's per capita income on inbound tourism and INTL_TOUR receipts is quite expected, as an overcrowded population damages scenic beauty and cultural heritage, which is less likely to increase international tourists visitation, while an increase in global economic growth tends to support INTL_TOUR infrastructure and INTL_TOUR revenues. The true cost of carbon emissions on INTL_TOUR would be enlarged when carbon damages, emissions of $\mathrm{CH}_{4}$ and $\mathrm{N}_{2} \mathrm{O}$, and population density increase INTL_TOUR expenditures due to the cost of healthcare, which increases global INTL_TOUR expenditures in order to improve air quality indicators. Thus, the given expectation is empirically analyzed by a sophisticated panel econometric technique, i.e., differenced panel Generalized Method of Moments (GMM), which was proposed by Arellano-Bond [55]. The Arellano-Bond dynamic panel GMM empirical specification is as follows:

follows:

$$
\begin{aligned}
& \ln \left(\begin{array}{l}
\text { INBOUND } \\
\operatorname{ITEXP} \\
\text { ITRCPT }
\end{array}\right\rangle_{i, t}=\alpha_{0}+\alpha_{1} \ln \left(\begin{array}{l}
\text { INBOUND } \\
\begin{array}{l}
\text { ITEXP } \\
\text { ITRCPT }
\end{array}
\end{array}\right\rangle_{i, t-1}+\alpha_{2} \ln \left(\mathrm{CO}_{2} \mathrm{DAM}\right)_{i, t}+\alpha_{3} \ln \left(\mathrm{CH}_{4}\right)_{i, t}+\alpha_{4} \ln \left(\mathrm{N}_{2} \mathrm{O}\right)_{i, t}
\end{aligned}
$$

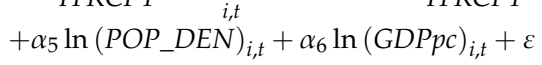

$$
\begin{aligned}
& \text { Instrumental - Variables } \\
& \ln \left(\begin{array}{l}
\operatorname{INBOUND} \\
\operatorname{ITEXP} \\
\text { ITRCPT }
\end{array}\right\rangle_{i, t-1}+\ln \left(\mathrm{CO}_{2} \_D A M\right)_{i, t-1}+\ln \left(\mathrm{CH}_{4}\right)_{i, t-1}+\ln \left(\mathrm{N}_{2} \mathrm{O}\right)_{i, t-1}+\ln \left(\text { POP_DEN }_{i, t-1}+\ln (G D P p c)_{i, t-1}\right.
\end{aligned}
$$

where ' $t-1$ ' represents the first lagged value.

Equation (4) shows the list of instrumental variables by taking the first lagged of the dependent variable as a regressor that is helpful to reduce the possible issues of serial correlation and heteroskedasticity, while in the regressors list, all the exogenous variables have been taken as first lagged values; hence, it reduces the possible issue of endogeneity issues from the given equation. The viability of using dynamic GMM estimator is due to the number of cross-sections being sufficiently larger than the number of a time period; thus, the given estimator provides an unbiased parameter estimate. The significance of the reported instrumental lists in the Equation (4) were checked by J-statistics and instrumental ranks, whereas the serial correlation issue was checked and corrected through $\mathrm{AR}(1)$ and $\mathrm{AR}(2)$ values.

\section{Results}

Table 3 shows the differenced GMM estimates and found that the cost of carbon emissions largely decreases inbound tourism, which ultimately reduces INTL_TOUR revenues. The estimated coefficients are less elastic in nature, as the cost of carbon emissions on inbound tourism revealed its high impact on INTL_TOUR receipts, which is about to decrease by $-0.164 \%$. Further, the impact of methane emissions and nitrous oxide emissions on INTL_TOUR is negative in the majority of cases, which implies that higher emissions of $\mathrm{CH}_{4}$ as a result of increased energy demand results in a decrease in the number of international tourist arrivals and INTL_TOUR revenues, which ultimately increases INTL_TOUR expenditures across countries. The differential impact of population density on INTL_TOUR is reported by the given estimation, as high population density decreases inbound tourism, which ultimately decreases INTL_TOUR expenditures and increases INTL_TOUR revenues. The positive impact of economic growth is quite visible on INTL_TOUR, which indicates that high economic growth is the vital factor to attract foreign tourists for healthy visitation. Sun [56] concluded that the tourism carbon footprint is a combination of technology embodied emissions, negative environmental externalities, and unsustainable production activities, which can be re-corrected through devising sustainable policies, for instance, adapting the cleaner production technologies, increase green R\&D expenditures, using low carbon fuels, biomass energy demand, and carbon taxes. All these factors would be helpful to implement the United Nations sustainable development agenda. Meng et al. [57] found that INTL_TOUR is highly intensified with carbon emissions thus its cost on INTL_TOUR industry is contractionary in nature. It is vital to devise sustainable INTL_TOUR policies 
by utilizing a sustainable mode of transportation, green technologies, and low carbon fuels to ensure the development of green INTL_TOUR infrastructure across countries. Zhang and Zhang [33] argued that carbon pricing is one of the desirable policy instruments that would be helpful to reduce the cost of carbon emissions on INTL_TOUR industry. Su [58] emphasized the need to develop a low carbon development INTL_TOUR industry to respond to the global call of green and sustainable INTL_TOUR agenda. The study devised three standing points of policy implications, i.e., the state should have to regulate environmental sustainability policies in order to limit INTL_TOUR carbon footprints, whereas tourists should have to act as responsible citizens and buy low carbon goods at tourists destination. Finally, enterprises should promote healthy competition and produce eco-friendly goods. Thus, these policies are in line with the United Nations policy guidelines to ensure sustainable INTL_TOUR worldwide. Kadir et al. [59] demonstrated the need to mitigate carbon emissions from the INTL_TOUR industry, as the INTL_TOUR industry supports a country's economic growth, resulting in a high ecological footprint due to INTL_TOUR expansion. Thus, the carbon emission is the ultimate cause of unsustainable INTL_TOUR expansion policies, which are limited by cleaner production technologies. Kasemsap [60] showed that carbon emissions negatively impact the socio-economic and environmental wellbeing of tourists and their selection of INTL_TOUR destination points. Thus, in order to provide for healthy visitation, the state should have to regulate INTL_TOUR associated carbon mitigation and produce eco-friendly goods in order to ensure sustainability agenda across countries.

Table 3. Arellano-Bond differenced GMM estimates.

\begin{tabular}{|c|c|c|c|}
\hline Variables & $\begin{array}{l}\text { Dependent Variable: } \\
\ln (\text { INBOUND) }\end{array}$ & $\begin{array}{c}\text { Dependent Variable: } \\
\ln (\text { ITEXP) }\end{array}$ & $\begin{array}{c}\text { Dependent Variable: } \\
\ln (\text { ITRCPT })^{\mathrm{a}}\end{array}$ \\
\hline $\ln (\text { INBOUND })_{\mathrm{t}-1}$ & $0.793^{*}$ & $-\cdots$ & $-\ldots$ \\
\hline $\ln (\text { ITEXP })_{\mathrm{t}-1}$ & $-\cdots-$ & $0.682^{*}$ & $-\cdots-$ \\
\hline $\ln (\mathrm{ITRCPT})_{\mathrm{t}-1}$ & $\ldots$ & $-\cdots$ & $0.530^{*}$ \\
\hline $\ln \left(\mathrm{CO}_{2} \mathrm{DAM}_{\mathrm{t}}\right.$ & $-0.002^{* *}$ & $0.161^{*}$ & $-0.164^{*}$ \\
\hline $\ln \left(\mathrm{CH}_{4}\right)_{\mathrm{t}}$ & $-0.010^{* * *}$ & $-0.257^{*}$ & $-0.234^{*}$ \\
\hline $\ln \left(\mathrm{N}_{2} \mathrm{O}\right)_{t}$ & $-0.089^{*}$ & $-0.179^{*}$ & 0.283 \\
\hline $\ln (\text { POP_DEN })_{t}$ & $-0.134^{*}$ & $-0.279^{*}$ & $1.440^{*}$ \\
\hline $\ln (\mathrm{GDPpc})_{\mathrm{t}}$ & $0.586^{*}$ & $0.219^{*}$ & $0.124^{*}$ \\
\hline \multicolumn{4}{|l|}{ Statistical Tests } \\
\hline J-statistics & 126.077 & 130.243 & 116.504 \\
\hline Prob. J-statistics & 0.506 & 0.403 & 0.189 \\
\hline Instrument rank & 133 & 133 & 132 \\
\hline $\mathrm{AR}(1)$-rho & -93.728 & -104.920 & $-175.850^{\mathrm{b} * *}$ \\
\hline AR(2)-rho & 1.260 & 5.324 & $36.359^{\mathrm{b}}$ \\
\hline
\end{tabular}

Note: ${ }^{*}, * *$, and ${ }^{* * *}$ shows $1 \%, 5 \%$, and $10 \%$ level of significance. a shows GMM orthogonal estimates. b shows differenced GMM estimates for AR bond.

The statistical tests confirmed that the J-statistics value greater than the critical region of $5 \%$ level of the confidence interval, thus the viability of the prescribed instrumental lists in the given regression is correct. The $\mathrm{AR}(1)$ and $\mathrm{AR}(2)$ value confirmed that the given model is free from the autocorrelation problem. Thus, the given estimates are unbiased and statistically correct. Table 4 shows the causality estimates that help us to understand the cause-effect relationships between the stated variables during a given time period. The results show that ITEXP Granger impact a country's per capita income, which supports to the TLG hypothesis. The number of earlier studies confirmed TLG hypothesis across different economic settings; for instance, Nassani et al. [25] emphasized the need to provide safe tourists visitation under armed protection, which substantiates the TLG hypothesis across countries. 
Qureshi et al. [23] discussed the viability of the positive impact of INTL_TOUR on economic growth that further translated into TLG hypothesis across the panel of countries. Lin et al. [61] confirmed the TLG hypothesis in most of the selected panel of countries for estimation and argued that INTL_TOUR is an engine of growth for larger geographical areas. Eyuboglu and Eyuboglu [62] confirmed the positive impacts of INTL_TOUR pertaining to the country's economic growth, thus supporting the TLG hypothesis in Turkey, Argentina, and the Philippines. Lee et al. [63] confirmed the positive relationship between INTL_TOUR and economic growth in the mediation of institutional quality in the context of the Malaysian economy and thus validated the TLG hypothesis.

The other causality estimates show that there is a unidirectional causality running from carbon emissions damage to population density and GDP per capita, methane emissions to inbound tourism, iii) population density to $\mathrm{N}_{2} \mathrm{O}$ emissions, and GDP per capita to $\mathrm{N}_{2} \mathrm{O}$ emissions, whereas there is a bidirectional causality between population density and GDP per capita. The following results have emerged with the causality estimates, i.e.,

5. INTL_TOUR revenue increases a country's economic growth, thus supporting the TLG hypothesis;

6. The cost of carbon emissions is largely confined to highly concentrated population areas;

7. Emissions from methane as a resulting factor of high energy demand decreases inbound tourism; and

8. Larger population pressure on arable land releases energy-associated nitrous oxide emissions.

\section{Discussion}

After analyzing the causality estimates, Table 5 shows the calculation of the cost of carbon emissions on INTL_TOUR for the next 10 years. For this purpose, the study utilized impulse response estimates and analyzed the carbon emissions damage to the INTL_TOUR in the inter-temporal forecasting process.

The results show that inbound tourism will substantially decline due to increase carbon emissions damage, $\mathrm{N}_{2} \mathrm{O}$ emissions, and population density, as the average change of $0.992 \%$ in the carbon emissions, $0.588 \%$ in $\mathrm{N}_{2} \mathrm{O}$ emissions, and $2.299 \%$ in population density led to a decrease inbound tourism of about $2.692 \%$ for the period 2020-2028. On the other hand, carbon emissions damage, population density, and country's GDP per capita increase INTL_TOUR expenditures by about 7.374\% for the next 10 years. Finally, the absolute change in carbon emissions damage largely decreases INTL_TOUR receipts by $5.165 \%$ over a time horizon. It is worth mentioning that carbon emissions damage largely increases INTL_TOUR expenditures and greatly decreases INTL_TOUR revenues due to degrowth in the tourists visiting tourism destination points across all countries. In order to analyze the cost of carbon emissions damage, Table A2 shows the variance error shocks pertaining to environmental factors and economic growth on INTL_TOUR for ready reference. The results show that population density will be the key contributing factor that shows greater variance error shock, i.e., $1.097 \%$ on inbound tourism, followed by carbon emissions damage, i.e., $0.223 \%$ and $\mathrm{N}_{2} \mathrm{O}$ emissions, i.e., $0.068 \%$. The least influenced will be $\mathrm{CH}_{4}$ emissions for the next 10 years. INTL_TOUR expenditures will largely be affected by high carbon emissions damage, i.e., $0.301 \%$ of GNI, followed by $\mathrm{N}_{2} \mathrm{O}$ emissions, i.e., $0.141 \%$, and population density, i.e., $0.031 \%$. The least influenced will be $\mathrm{CH}_{4}$ emissions over a time horizon. Finally, INTL_TOUR receipts will largely be affected by $\mathrm{CH}_{4}$ emissions, i.e., $0.074 \%$, followed by GDP per capita and $\mathrm{N}_{2} \mathrm{O}$ emissions. The least influenced will be carbon emissions damage with a variance error shock of $0.008 \%$ for the next 10 years time period. 
Table 4. VAR Granger causality test.

\begin{tabular}{|c|c|c|c|c|c|c|c|c|}
\hline Variables & $\sum \ln (\mathrm{INBOUND})_{\mathrm{t}-1}$ & $\sum \ln (\operatorname{ITEXP})_{\mathrm{t}-1}$ & $\sum \ln (\text { ITRCPT })_{\mathrm{t}-1}$ & $\sum \ln \left(\mathrm{CO} 2 \_\mathrm{DAM}\right)_{\mathrm{t}-1}$ & $\sum \ln \left(\mathrm{CH}_{4}\right)_{\mathrm{t}-1}$ & $\sum \ln \left(\mathrm{N}_{2} \mathrm{O}\right)_{\mathrm{t}-1}$ & $\sum \ln (\text { POP_DEN })_{\mathrm{t}-1}$ & $\sum \ln (\text { GDPpc })_{t-1}$ \\
\hline$\sum \ln (\mathrm{INBOUND})_{\mathrm{t}}$ & $\ldots--$ & N/A & $\mathrm{N} / \mathrm{A}$ & Й & $\breve{~}$ & $\breve{~}$ & Й & Й \\
\hline$\sum \ln (\mathrm{ITEXP})_{\mathrm{t}}$ & $\mathrm{N} / \mathrm{A}$ & $\ldots-$ & N/A & Й & $\breve{И}$ & Й & Й & $\rightarrow$ \\
\hline$\sum \ln (\mathrm{ITRCPT})_{\mathrm{t}}$ & N/A & $\mathrm{N} / \mathrm{A}$ & $-\cdots$ & Й & $\breve{И}$ & $\breve{И}$ & $\breve{И}$ & Й \\
\hline$\sum \ln \left(\mathrm{CO}_{2} \mathrm{DAM}\right)_{\mathrm{t}}$ & $\breve{~}$ & Й & Й & $\ldots-$ & $\leftrightarrow$ & & $\rightarrow$ & $\rightarrow$ \\
\hline$\sum \ln \left(\mathrm{CH}_{4}\right)_{\mathrm{t}}$ & $\rightarrow$ & Й & Й & $\leftrightarrow$ & $\cdots-$ & $\leftrightarrow$ & Й & Й \\
\hline$\sum \ln \left(\mathrm{N}_{2} \mathrm{O}\right)_{\mathrm{t}}$ & Й & Й & Й & Й & $\leftrightarrow$ & $\ldots--$ & Й & Й \\
\hline$\sum \ln (\text { POP_DEN })_{\mathrm{t}}$ & $\rightarrow$ & Й & Й & Й & Й & $\rightarrow$ & $\ldots-$ & $\leftrightarrow$ \\
\hline$\sum \ln (\mathrm{GDPpc})_{\mathrm{t}}$ & $\breve{~}$ & Й & $\breve{И}$ & $\breve{И}$ & Й & $\rightarrow$ & $\leftrightarrow$ & $-\ldots$ \\
\hline
\end{tabular}

Table 5. Cost of carbon emissions on international tourism over a time horizon.

\begin{tabular}{|c|c|c|c|c|c|c|c|c|c|c|}
\hline Time Period & $\begin{array}{c}\ln (\text { INBOUND) } \\
(\%)\end{array}$ & $\begin{array}{c}\ln \left(\mathrm{CO}_{2 \_} \mathrm{DAM}\right) \\
(\%)\end{array}$ & $\ln \left(\mathrm{N}_{2} \mathrm{O}\right)(\%)$ & $\underset{(\%)}{\ln (\text { POP_DEN) }}$ & $\ln (\operatorname{ITEXP})(\%)$ & $\underset{(\%)}{\ln \left(\mathrm{CO}_{2 \_} \mathrm{DAM}\right)}$ & $\underset{(\%)}{\ln (\text { POP_DEN) }}$ & $\begin{array}{c}\ln (\text { GDPpc) } \\
(\%)\end{array}$ & $\begin{array}{c}\ln (\text { ITRCPT }) \\
(\%)\end{array}$ & $\underset{(\%)}{\ln \left(\mathrm{CO}_{2 \_} \mathrm{DAM}\right)}$ \\
\hline 2020 & 19.546 & 0.357 & -0.141 & -0.523 & 19.758 & 0.832 & 0.080 & 0.006 & 23.362 & 0.397 \\
\hline 2021 & 19.183 & 0.482 & -0.204 & -0.989 & 18.674 & 0.897 & 0.152 & 0.007 & 23.162 & 0.312 \\
\hline 2022 & 18.820 & 0.614 & -0.294 & -1.394 & 17.611 & 0.937 & 0.215 & 0.009 & 22.310 & 0.254 \\
\hline 2023 & 18.468 & 0.746 & -0.378 & -1.742 & 16.608 & 0.966 & 0.269 & 0.122 & 21.578 & 0.188 \\
\hline 2024 & 18.125 & 0.875 & -0.464 & -2.038 & 15.662 & 0.988 & 0.315 & 0.146 & 20.856 & 0.124 \\
\hline 2025 & 17.793 & 1.000 & -0.584 & -2.290 & 14.769 & 1.005 & 0.352 & 0.168 & 20.159 & 0.0624 \\
\hline 2026 & 17.471 & 1.121 & -0.631 & -2.500 & 13.927 & 1.016 & 0.383 & 0.188 & 19.484 & 0.0020 \\
\hline 2027 & 17.158 & 1.238 & -0.713 & -2.676 & 13.133 & 1.023 & 0.408 & 0.206 & 18.830 & -0.056 \\
\hline 2028 & 16.854 & 1.349 & -0.729 & -2.822 & 12.384 & 1.025 & 0.428 & 0.222 & 18.197 & -0.113 \\
\hline $\begin{array}{l}\text { Absolute Change } \\
(2020-2028)(\%)\end{array}$ & 2.692 & 0.992 & $|-0.588|$ & $|-2.299|$ & 7.374 & 0.193 & 0.348 & 0.216 & 5.165 & 0.284 \\
\hline
\end{tabular}




\section{Conclusions}

The United Nations sustainable development agenda has largely provoked the need of carbon-free tourism that would be possible to attain by devising green international tourism (INTL_TOUR) policies, sustainable consumption and production, green logistics operations, and strict environmental regulations. All these factors are helpful to provide a pathway toward eco-friendly tourism. The study identified the cost of carbon emissions in INTL_TOUR by utilizing a large panel of heterogeneous countries for the period of 1995-2018. The study employed a differenced panel GMM estimator to obtain unbiased parameter estimates, which is free of the serial correlation problem, heteroskedasticity, and the endogeneity issue. Further, the study used Granger causality estimates to find the causal relationships between the stated variables. Finally, the study used an innovation accounting matrix in order to find the cost of carbon emissions on INTL_TOUR across countries. The results show that the cost of carbon emissions is quite visible in terms of decreasing inbound tourism and INTL_TOUR receipts, as was its resulting impact on increasing INTL_TOUR expenditures in a panel of selected countries. The results confirmed one-way causal relationships between INTL_TOUR receipts and country's economic growth, which supported the TLG hypothesis; $\mathrm{CH}_{4}$ emissions to inbound tourism to support the emissions-led tourism hypothesis; population led nitrous oxide emissions; and growth led $\mathrm{N}_{2} \mathrm{O}$ emissions, whereas there was a feedback relationship found between economic growth and population density across countries.

The list of possible policy implications that are derived from the given results are as follows:

1. The cost of carbon emissions on INTL_TOUR is uncomfortable in the variety of ways, i.e., the significant decline of inbound tourism due to high carbon emissions in the tourists' destination, a decrease in the INTL_TOUR receipts, an increase in INTL_TOUR expenditures, and exacerbate energy associated emissions. All these factors interfere with the sustainable INTL_TOUR agenda. There is a high need to mitigate carbon emissions through sustainable production and consumption, tight environmental regulations, controlled population growth, advancement in cleaner production, and continued economic growth. These factors an increase international tourists' arrival, thus increasing INTL_TOUR revenues and reducing INTL_TOUR expenditures.

2. Energy-associated emissions largely increase due to increased economic activities, which are generated through the expansion of INTL_TOUR. Thus, it is vital to substitute non-renewable fuels with renewable fuel in order to regulate sustainable INTL_TOUR agenda.

3. The development of resilient tourism infrastructure is necessary in order to attract more foreign tourists through promoting safe and healthy visitation, using eco-friendly goods, using electrified vehicles, taking care cultural heritage, maintaining rural beauty, and selling the healthy INTL_TOUR vision.

4. The mission and vision agenda of sustainable INTL_TOUR should be the key priority for global policymakers and should be in line it with medical tourism, e-tourism, and digital marketing, which sells online healthcare services, insurance coverage, online tourists destination web marketing, and hotels booking, etc. All these facilities will attract international tourists and increase their length of stay in the host countries.

5. Carbon pricing is considered the optimal strategy to impose tariffs on dirty production in order to limit an enormous amount of energy-based emissions. Thus, this strategy could be used in a way to reduced tourism carbon footprints and increasing INTL_TOUR revenues with healthy visitation to destination points.

These policies are largely supported by and in line with the United Nations tourism support agenda and can help to achieve environmental sustainability through advancements in cleaner production technologies, sustainable production and consumption, and carbon pricing. The ecological footprint of INTL_TOUR is one of the main factors that need to be addressed with sustainable policies. Future studies may contribute in three different dimensions: first, future studies can extend the given modelling framework by adding a few more important variables that may significantly impact on 
INTL_TOUR, i.e., R\&D expenditures, patent rights, and trademarks, which can be used as a proxy for technological innovation. Scientific and technical publications can be used for knowledge innovation, and trade openness could be used for a proxy of globalization. Second, regional contribution can be explored for sustainable tourism modelling. Finally, more robust statistical techniques can be used-for instance, a pooled ARDL-Bounds testing approach can be used to handle serial correlation issues in the given model.

Author Contributions: Conceptualization, M.K.A.; methodology, Z.Y.; investigation and conclusions, U.A.; formal analysis, A.A.N.; writing-review and editing, M.M.Q.A. and A.A.N.; and data curation, K.Z. All authors have read and agreed to the published version of the manuscript.

Funding: Researchers Supporting Project number (RSP-2019/87), King Saud University, Riyadh, Saudi Arabia.

Acknowledgments: Researchers Supporting Project number (RSP-2019/87), King Saud University, Riyadh, Saudi Arabia.

Conflicts of Interest: The authors declare no conflict of interest. 


\section{Appendix A}

Table A1. List of sample countries.

\begin{tabular}{|c|c|c|c|c|c|c|c|c|c|c|c|c|c|}
\hline Albania & Belgium & Canada & $\begin{array}{l}\text { Dominican } \\
\text { Republic }\end{array}$ & Georgia & Indonesia & Korea & Maldives & Namibia & Paraguay & Senegal & St. Lucia & Tunisia & Zambia \\
\hline Algeria & Benin & Chile & Ecuador & Germany & Iran & $\begin{array}{c}\text { Kyrgyz } \\
\text { Republic }\end{array}$ & Mali & Nepal & Peru & Seychelles & Suriname & Turkey & Zimbabwe \\
\hline Angola & Bolivia & China & Egypt & Ghana & Iraq & Latvia & Malta & Netherland & Philippine & $\begin{array}{l}\text { Sierra } \\
\text { Leone }\end{array}$ & Sweden & Uganda & \multirow{8}{*}{ 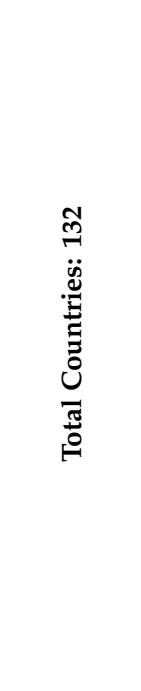 } \\
\hline Argentina & $\begin{array}{l}\text { Bosnia and } \\
\text { Herzegovina }\end{array}$ & Colombia & $\begin{array}{c}\text { El } \\
\text { Salvador }\end{array}$ & Greece & Ireland & Lebanon & Mauritius & $\begin{array}{c}\text { New } \\
\text { Zealand }\end{array}$ & Poland & Singapore & Switzerland & Ukraine & \\
\hline Armenia & Botswana & $\begin{array}{c}\text { Congo, } \\
\text { Dem. Rep. }\end{array}$ & Estonia & Guatemala & Italy & Lesotho & Mexico & Niger & Portugal & $\begin{array}{c}\text { Slovak } \\
\text { Republic }\end{array}$ & Tajikistan & $\begin{array}{l}\text { United } \\
\text { Kingdom }\end{array}$ & \\
\hline Australia & Brazil & Costa Rica & Ethiopia & Guyana & Jamaica & Libya & Moldova & Nigeria & Romania & Slovenia & Tanzania & $\begin{array}{l}\text { United } \\
\text { States }\end{array}$ & \\
\hline Austria & $\begin{array}{c}\text { Brunei } \\
\text { Darussalam }\end{array}$ & $\begin{array}{c}\text { Cote } \\
\text { d'Ivoire }\end{array}$ & Finland & Haiti & Japan & Lithuania & Mongolia & Norway & $\begin{array}{l}\text { Russian } \\
\text { Federation }\end{array}$ & Solomon & Thailand & Uruguay & \\
\hline Bangladesh & Bulgaria & Croatia & France & Hungary & Jordan & Luxembourg & Morocco & Pakistan & Rwanda & $\begin{array}{l}\text { South } \\
\text { Africa }\end{array}$ & Timor-Leste & Vanuatu & \\
\hline Azerbaijan & Cambodia & Cyprus & Gabon & Iceland & Kazakhstan & Madagascar & Mozambique & Panama & Samoa & Spain & Togo & $\begin{array}{l}\text { Venezuela, } \\
\text { RB }\end{array}$ & \\
\hline Belarus & Cameroon & $\begin{array}{l}\text { Czech } \\
\text { Republic }\end{array}$ & Gambia & India & Kenya & Malaysia & Myanmar & $\begin{array}{l}\text { Papua } \\
\text { New } \\
\text { Guinea }\end{array}$ & $\begin{array}{l}\text { Saudi } \\
\text { Arabia }\end{array}$ & Sri Lanka & Tonga & Vietnam & \\
\hline
\end{tabular}


Table A2. VDA estimates.

\begin{tabular}{|c|c|c|c|c|c|c|c|}
\hline \multicolumn{8}{|c|}{$\ln (\mathrm{INBOUND})$} \\
\hline Period & S.E. & $\ln (\mathrm{INBOUND})$ & $\ln \left(\mathrm{CO}_{2} \_\mathrm{DAM}\right)$ & $\ln \left(\mathrm{CH}_{4}\right)$ & $\ln \left(\mathrm{N}_{2} \mathrm{O}\right)$ & $\ln ($ POP_DEN) & $\ln ($ GDPpc) \\
\hline 2019 & 0.201 & 100 & 0 & 0 & 0 & 0 & 0. \\
\hline 2020 & 0.280 & 99.915 & 0.016 & 0.002 & 0.002 & 0.034 & 0.028 \\
\hline 2021 & 0.340 & 99.809 & 0.031 & 0.004 & 0.005 & 0.108 & 0.040 \\
\hline 2022 & 0.389 & 99.678 & 0.048 & 0.005 & 0.009 & 0.211 & 0.046 \\
\hline 2023 & 0.431 & 99.523 & 0.069 & 0.005 & 0.015 & 0.335 & 0.049 \\
\hline 2024 & 0.468 & 99.351 & 0.094 & 0.006 & 0.023 & 0.473 & 0.051 \\
\hline 2025 & 0.501 & 99.165 & 0.121 & 0.006 & 0.032 & 0.621 & 0.052 \\
\hline 2026 & 0.531 & 98.971 & 0.152 & 0.007 & 0.042 & 0.773 & 0.052 \\
\hline 2027 & 0.559 & 98.770 & 0.186 & 0.007 & 0.054 & 0.927 & 0.053 \\
\hline 2028 & 0.585 & 98.566 & 0.223 & 0.008 & 0.068 & 1.079 & 0.053 \\
\hline \multicolumn{8}{|c|}{$\ln ($ ITEXP) } \\
\hline Period & S.E. & $\ln ($ ITEXP) & $\ln \left(\mathrm{CO}_{2} \_\mathrm{DAM}\right)$ & $\ln \left(\mathrm{CH}_{4}\right)$ & $\ln \left(\mathrm{N}_{2} \mathrm{O}\right)$ & $\ln$ (POP_DEN) & $\ln ($ GDPpc) \\
\hline 2019 & 0.217 & 100 & 0 & 0 & 0 & 0 & 0 \\
\hline 2020 & 0.293 & 99.913 & 0.080 & 0.0001 & 0.004 & 0.0007 & 0.0005 \\
\hline 2021 & 0.348 & 99.860 & 0.123 & 0.0006 & 0.011 & 0.002 & 0.0007 \\
\hline 2022 & 0.390 & 99.814 & 0.155 & 0.001 & 0.021 & 0.005 & 0.0012 \\
\hline 2023 & 0.424 & 99.768 & 0.183 & 0.001 & 0.035 & 0.008 & 0.0018 \\
\hline 2024 & 0.452 & 99.721 & 0.209 & 0.002 & 0.051 & 0.012 & 0.0027 \\
\hline 2025 & 0.476 & 99.672 & 0.233 & 0.003 & 0.070 & 0.016 & 0.0037 \\
\hline 2026 & 0.496 & 99.620 & 0.256 & 0.004 & 0.091 & 0.021 & 0.0048 \\
\hline 2027 & 0.513 & 99.567 & 0.279 & 0.005 & 0.115 & 0.026 & 0.0061 \\
\hline 2028 & 0.528 & 99.511 & 0.301 & 0.006 & 0.141 & 0.031 & 0.0075 \\
\hline \multicolumn{8}{|c|}{$\ln (\mathrm{ITRCPT})$} \\
\hline Period & S.E. & $\ln (\mathrm{ITRCPT})$ & $\ln \left(\mathrm{CO} 2 \_\mathrm{DAM}\right)$ & $\ln \left(\mathrm{CH}_{4}\right)$ & $\ln \left(\mathrm{N}_{2} \mathrm{O}\right)$ & $\ln ($ POP_DEN) & $\ln ($ GDPpc) \\
\hline 1 & 0.282 & 100 & 0 & 0 & 0 & 0 & 0 \\
\hline 2 & 0.366 & 99.963 & 0.011 & 0.012 & 0.0028 & 0.0012 & 0.008 \\
\hline 3 & 0.433 & 99.946 & 0.013 & 0.019 & 0.0021 & 0.003 & 0.014 \\
\hline 4 & 0.487 & 99.932 & 0.013 & 0.027 & 0.0023 & 0.005 & 0.018 \\
\hline 5 & 0.533 & 99.918 & 0.012 & 0.034 & 0.0040 & 0.007 & 0.022 \\
\hline 6 & 0.573 & 99.903 & 0.011 & 0.041 & 0.0070 & 0.010 & 0.026 \\
\hline 7 & 0.607 & 99.887 & 0.010 & 0.049 & 0.011 & 0.012 & 0.029 \\
\hline 8 & 0.638 & 99.869 & 0.009 & 0.057 & 0.017 & 0.014 & 0.032 \\
\hline 9 & 0.665 & 99.849 & 0.008 & 0.065 & 0.023 & 0.016 & 0.035 \\
\hline 10 & 0.689 & 99.828 & 0.008 & 0.074 & 0.032 & 0.018 & 0.038 \\
\hline
\end{tabular}

\section{References}

1. Borel-Saladin, J.M.; Turok, I.N. The green economy: Incremental change or transformation? Environ. Policy Gov. 2013, 23, 209-220. [CrossRef]

2. Malik, M.A.S.; Shah, S.A.; Zaman, K. Tourism in Austria: Biodiversity, environmental sustainability, and growth issues. Environ. Sci. Pollut. Res. 2016, 23, 24178-24194. [CrossRef] [PubMed] 
3. Zaman, K.; Khan, M.M.; Ahmad, M. Exploring the relationship between tourism development indicators and carbon emissions: A case study of Pakistan. World Appl. Sci. J. 2011, 15, 690-701.

4. UNWTO. International Tourism Highlights-2019. United Nation World Tourism Organization. Available online: https://www.e-unwto.org/doi/pdf/10.18111/9789284421152 (accessed on 7 January 2020).

5. The New York Times. Carbon Dioxide Emissions Hit a Record in 2019, Even as Coal Fades. 2019. Available online: https://www.nytimes.com/2019/12/03/climate/carbon-dioxide-emissions.html (accessed on 7 January 2020).

6. Hall, C.M. Constructing sustainable tourism development: The 2030 agenda and the managerial ecology of sustainable tourism. J. Sustain. Tour. 2019, 27, 1044-1060. [CrossRef]

7. Zha, J.; Tan, T.; Yuan, W.; Yang, X.; Zhu, Y. Decomposition analysis of tourism CO2 emissions for sustainable development: A case study of China. Sustain. Dev. 2020, 28, 169-186. [CrossRef]

8. Ristić, D.; Vukoičić, D.; Milinčić, M. Tourism and sustainable development of rural settlements in protected areas-Example NP Kopaonik (Serbia). Land Use Policy 2019, 89, 104231.

9. Wall, G. Tourism and development: Towards sustainable outcomes. In Cultural Tourism and Sustainable Local Development; Routledge: London, UK, 2016; pp. 49-64.

10. Hunter, C.; Shaw, J. The ecological footprint as a key indicator of sustainable tourism. Tour. Manag. 2007, 28, 46-57. [CrossRef]

11. Awan, U.; Kraslawski, A.; Huiskonen, J. Governing interfirm relationships for social sustainability: The relationship between governance mechanisms, sustainable collaboration, and cultural intelligence. Sustainability 2018, 10, 4473. [CrossRef]

12. Awan, U.; Sroufe, R.; Kraslawski, A. Creativity enables sustainable development: Supplier engagement as a boundary condition for the positive effect on green innovation. J. Clean. Prod. 2019, 226, 172-185. [CrossRef]

13. Arshad, Z.; Robaina, M.; Shahbaz, M.; Veloso, A.B. The effects of deforestation and urbanization on sustainable growth in Asian countries. Environ. Sci. Pollut. Res. 2020, 1-22. [CrossRef]

14. Pan, S.Y.; Gao, M.; Kim, H.; Shah, K.J.; Pei, S.L.; Chiang, P.C. Advances and challenges in sustainable tourism toward a green economy. Sci. Total Environ. 2018, 635, 452-469. [CrossRef] [PubMed]

15. Tiwari, A.K.; Ozturk, I.; Aruna, M. Tourism, energy consumption and climate change in OECD countries. Int. J. Energy Econ. Policy 2013, 3, 247-261.

16. Lee, J.W.; Brahmasrene, T. Investigating the influence of tourism on economic growth and carbon emissions: Evidence from panel analysis of the European Union. Tour. Manag. 2013, 38, 69-76. [CrossRef]

17. Sajjad, F.; Noreen, U.; Zaman, K. Climate change and air pollution jointly creating nightmare for tourism industry. Environ. Sci. Pollut. Res. 2014, 21, 12403-12418. [CrossRef]

18. Ozturk, I.; Al-Mulali, U.; Saboori, B. Investigating the environmental Kuznets curve hypothesis: The role of tourism and ecological footprint. Environ. Sci. Pollut. Res. 2016, 23, 1916-1928. [CrossRef]

19. Ozturk, I. The relationships among tourism development, energy demand, and growth factors in developed and developing countries. Int. J. Sustain. Dev. World. 2016, 23, 122-131. [CrossRef]

20. Bac, D.P.; Aksoz, E.O. Contemporary Challenges for Sustainable Tourism-A Regional Perspective. Oradea J. Bus. Econ. 2017, 2, 37-44.

21. Tang, C.F.; Tiwari, A.K.; Shahbaz, M. Dynamic inter-relationships among tourism, economic growth and energy consumption in India. Geosyst. Eng. 2016, 19, 158-169. [CrossRef]

22. Zaman, K.; Shahbaz, M.; Loganathan, N.; Raza, S.A. Tourism development, energy consumption and Environmental Kuznets Curve: Trivariate analysis in the panel of developed and developing countries. Tour. Manag. 2016, 54, 275-283. [CrossRef]

23. Qureshi, M.I.; Hassan, M.A.; Hishan, S.S.; Rasli, A.M.; Zaman, K. Dynamic linkages between sustainable tourism, energy, health and wealth: Evidence from top 80 international tourist destination cities in 37 countries. J. Clean. Prod. 2017, 158, 143-155. [CrossRef]

24. Zaman, K.; Moemen, M.A.E.; Islam, T. Dynamic linkages between tourism transportation expenditures, carbon dioxide emission, energy consumption and growth factors: Evidence from the transition economies. Curr. Issues Tour. 2017, 20, 1720-1735. [CrossRef]

25. Nassani, A.A.; Zaman, K.; Aldakhil, A.M.; Abro, M.M.Q. War economy and pleasure: Assessing the effects of military expenditure on tourism growth. Qual. Quan. 2017, 51, 1733-1754. [CrossRef] 
26. Khan, S.A.R.; Qianli, D.; SongBo, W.; Zaman, K.; Zhang, Y. Travel and tourism competitiveness index: The impact of air transportation, railways transportation, travel and transport services on international inbound and outbound tourism. J. Air Transp. Manag. 2017, 58, 125-134. [CrossRef]

27. Paramati, S.R.; Shahbaz, M.; Alam, M.S. Does tourism degrade environmental quality? A comparative study of Eastern and Western European Union. Transport. Res. Part D Transp. Environ. 2017, 50, 1-13. [CrossRef]

28. Nassani, A.A.; Aldakhil, A.M.; Abro, M.M.Q.; Zaman, K. Effective international tourism management: A strategic approach. Soc. Indic. Res. 2018, 137, 1201-1224. [CrossRef]

29. Bhuiyan, M.A.; Zaman, K.; Shoukry, A.M.; Gani, S.; Sharkawy, M.A.; Sasmoko Khan, A.; Ahmad, A.; Hishan, S.S. Energy, tourism, finance, and resource depletion: Panel data analysis. Energy Source Part B 2018, 13, 463-474. [CrossRef]

30. Shaheen, K.; Zaman, K.; Batool, R.; Khurshid, M.A.; Aamir, A.; Shoukry, A.M.; Sharkawy, M.A.; Aldeek, F.; Khader, J.; Gani, S. Dynamic linkages between tourism, energy, environment, and economic growth: Evidence from top 10 tourism-induced countries. Environ. Sci. Pollut. Res. 2019, 26, 31273-31283. [CrossRef]

31. Anser, M.K.; Yousaf, Z.; Nassani, A.A.; Abro, M.M.Q.; Zaman, K. International tourism, social distribution, and environmental Kuznets curve: Evidence from a panel of G-7 countries. Environ. Sci. Pollut. Res. 2019, 27, 1-14. [CrossRef]

32. Ali, G.; Zaman, K.; Islam, T. Macroeconomic shocks and Malaysian Tourism Industry: Evidence from a structural VAR model. Iran. Econ. Rev. 2018, 22, 1113-1137.

33. Zhang, L.; Zhang, J. A systematic review on tourism energy consumption, sustainable tourism, and destination development: A behavioral perspective. In Transport and Energy Research; Elsevier: Amsterdam, The Netherlands, 2020; pp. 295-313.

34. Tang, J.; Yuan, X.; Ramos, V.; Sriboonchitta, S. Does air pollution decrease inbound tourist arrivals? The case of Beijing. Asia Pac. J. Tour. Res. 2019, 24, 597-605. [CrossRef]

35. Qureshi, M.I.; Elashkar, E.E.; Shoukry, A.M.; Aamir, A.; Mahmood, N.H.N.; Rasli, A.M.; Zaman, K. Measuring the ecological footprint of inbound and outbound tourists: Evidence from a panel of 35 countries. Clean. Technol. Environ. 2019, 21, 1949-1967. [CrossRef]

36. Balsalobre-Lorente, D.; Driha, O.M.; Shahbaz, M.; Sinha, A. The effects of tourism and globalization over environmental degradation in developed countries. Environ. Sci. Pollut. Res. 2019, 1-15. [CrossRef] [PubMed]

37. Manzoor, F.; Wei, L.; Asif, M. The Contribution of Sustainable Tourism to Economic Growth and Employment in Pakistan. Int. J. Environ. Res. Public Health 2019, 16, 3785. [CrossRef] [PubMed]

38. Khan, M.T.I.; Yaseen, M.R.; Ali, Q. Nexus between financial development, tourism, renewable energy, and greenhouse gas emission in high-income countries: A continent-wise analysis. Energy Econ. 2019, 83, $293-310$. [CrossRef]

39. He, L.; Zha, J.; Loo, H.A. How to improve tourism energy efficiency to achieve sustainable tourism: Evidence from China. Curr. Issues Tour. 2020, 23, 1-16. [CrossRef]

40. Liu, Y.; Kumail, T.; Ali, W.; Sadiq, F. The dynamic relationship between CO2 emission, international tourism and energy consumption in Pakistan: A cointegration approach. Tour. Rev. 2019, 74, 761-779. [CrossRef]

41. Sghaier, A.; Guizani, A.; Jabeur, S.B.; Nurunnabi, M. Tourism development, energy consumption and environmental quality in Tunisia, Egypt and Morocco: A trivariate analysis. GeoJournal 2019, 84, 593-609. [CrossRef]

42. Koçak, E.; Ulucak, R.; Ulucak, Z.Ş. The impact of tourism developments on CO2 emissions: An advanced panel data estimation. Tour. Manag. Perspect. 2020, 33, 100611. [CrossRef]

43. Huiyue, L.; Meng, Z. Estimating the influence of tourism and economic growth on carbon emissions: The case of China. In Proceedings of the 2019 4th International Conference on Social Sciences and Economic Development (ICSSED 2019), Wuhan, China, 15-17 March 2019; Atlantis Press: Paris, France, 2019.

44. Shakouri, B.; Khoshnevis Yazdi, S.; Ghorchebigi, E. Does tourism development promote CO2 emissions? Anatolia 2017, 28, 444-452. [CrossRef]

45. Tang, C.; Zhong, L.; Ng, P. Factors that influence the tourism industry's carbon emissions: A tourism area life cycle model perspective. Energy Policy 2017, 109, 704-718. [CrossRef]

46. Chen, L.; Thapa, B.; Yan, W. The relationship between tourism, carbon dioxide emissions, and economic growth in the Yangtze River Delta, China. Sustainability 2018, 10, 2118. [CrossRef] 
47. Nepal, R.; al Irsyad, M.I.; Nepal, S.K. Tourist arrivals, energy consumption and pollutant emissions in a developing economy-implications for sustainable tourism. Tour. Manag. 2019, 72, 145-154. [CrossRef]

48. Unger, R.; Abegg, B.; Mailer, M.; Stampfl, P. Energy consumption and greenhouse gas emissions resulting from tourism travel in an alpine setting. Mt. Res. Dev. 2016, 36, 475-484. [CrossRef]

49. Becken, S.; Patterson, M. Measuring national carbon dioxide emissions from tourism as a key step towards achieving sustainable tourism. J. Sustain. Tour. 2016, 14, 323-338. [CrossRef]

50. Scott, D.; Gössling, S.; Hall, C.M.; Peeters, P. Can tourism be part of the decarbonized global economy? The costs and risks of alternate carbon reduction policy pathways. J. Sustain. Tour. 2016, 24, 52-72. [CrossRef]

51. World Bank. World Development Indicator; World Bank: Washington, DC, USA, 2019.

52. Solow, R.M. A contribution to the theory of economic growth. Q. J. Econ. 1956, 70, 65-94. [CrossRef]

53. Dogru, T.; Bulut, U. Is tourism an engine for economic recovery? Theory and empirical evidence. Tour. Manag. 2018, 67, 425-434. [CrossRef]

54. Pato, L. Steering tourism as an engine for economic growth in Africa: Opportunities and challenges. AfricaGrowth Agenda 2019, 16, 20-21.

55. Arellano, M.; Bond, S. Some tests of specification for panel data: Monte Carlo evidence and an application to employment equations. Rev. Econ. Stud. 1991, 58, 277-297. [CrossRef]

56. Sun, Y.Y. Decomposition of tourism greenhouse gas emissions: Revealing the dynamics between tourism economic growth, technological efficiency, and carbon emissions. Tour. Manag. 2016, 55, 326-336. [CrossRef]

57. Meng, W.; Xu, L.; Hu, B.; Zhou, J.; Wang, Z. Quantifying direct and indirect carbon dioxide emissions of the Chinese tourism industry. J. Clean. Prod. 2016, 126, 586-594. [CrossRef]

58. Su, J. Impact of tourism resource development based on low-carbon mode: A case study of Guizhou ethnic areas. Ecol. Processes 2019, 8, 21. [CrossRef]

59. Kadir, N.; Nayan, S.; Noor, A.N.M.; Zakaria, D.A. Tourism, Carbon Dioxide Emissions and Economic Growth: Evidence from Panel Data. In Proceedings of the Second International Conference on the Future of ASEAN (ICoFA) 2017-Volume 1; Springer: Singapore, 2009; pp. 391-398.

60. Kasemsap, K. Sustainability, environmental sustainability, and sustainable tourism: Advanced issues and implications. In Environmental and Agricultural Informatics: Concepts, Methodologies, Tools, and Applications; IGI Global: Hershey, PA, USA, 2020; pp. 1669-1687.

61. Lin, V.S.; Yang, Y.; Li, G. Where can tourism-led growth and economy-driven tourism growth occur? J. Travel Res. 2019, 58, 760-773. [CrossRef]

62. Eyuboglu, S.; Eyuboglu, K. Tourism development and economic growth: An asymmetric panel causality test. Curr. Issues Tour. 2019, 1-7. [CrossRef]

63. Lee, H.S.; Sin Yee, L.E.E.; Har, W.M. Roles of Institutional Quality on the Relationship between Tourism and Economic Development in Malaysia. J. Environ. Treat. Tech. 2020, 8, 119-124. [CrossRef] 